\title{
Cluster organization of extractive industries in northern regions: a comprehensive assessment method
}

\section{Organización en clúster de industrias extractivas en las regiones del norte: un método de evaluación integral}

\author{
Valentina V. Nikiforova, Elena E. Grigoryeva*, Petr V. Gulyaev, Grigoriy S. Kovrov, \\ Nikolay N. Konstantinov \\ Scientific-Research Institute of Regional Economy of the North, North-Eastern Federal University, \\ Yakutsk, Russia \\ *elena.grigoreva80@mail.ru
}

(recibido/received: 25-enero-2021; aceptado/accepted: 29-abril-2021)

\begin{abstract}
The spatial organization of productive forces, the efficient use of available facilities, and the production potential assessment of economic sectors in a given region are topical issues. The Republic of Sakha (Yakutia) is a large resource-dependent region of Russia, remarkable for the geographical dispersion of deposits over a vast territory and the complex transport and power supply infrastructures. This paper presents a comprehensive assessment of the feasibility of cluster organization in the subsoil use sector in the Republic of Sakha (Yakutia), the Russian Federation, factoring in the existing and prospective economic zoning and the existing potential. The republic was divided into zones based on a cluster framework of the subsoil users. The study used statistical data on the municipal districts and financial indicators of the extractive industry companies. The integrated method was applied in the assessment, and the performance index of the identified cluster territories was calculated on a tenpoint scale. The identified zones were rated by resource and production potential. The general cluster zone performance index was calculated. It appeared feasible to cluster the extractive industry in the studied region as it can increase competitiveness of local companies and contribute to the socioeconomic development of its municipal districts. The proposed method can be applied for comprehensive assessment of the subsoil use sector in northern territories.
\end{abstract}

Keywords: spatial organization, clustering, subsoil use, assessment methodology, rating, Northern region.

\section{RESUMEN}

La organización espacial de las fuerzas productivas, el uso eficiente de las instalaciones disponibles y la evaluación del potencial productivo de los sectores económicos de una región determinada son temas de actualidad. La República de Sakha (Yakutia) es una gran región de Rusia dependiente de los recursos, notable por la dispersión geográfica de los depósitos en un vasto territorio y las complejas infraestructuras de transporte y suministro de energía. Este documento presenta una evaluación integral de la viabilidad de la organización de clusters en el sector de uso del subsuelo en la República de Sakha (Yakutia), Federación de Rusia, teniendo en cuenta la zonificación económica existente y prospectiva y el potencial existente. La república se dividió en zonas basadas en un marco de clúster de los usuarios del subsuelo. El estudio utilizó datos estadísticos de los distritos municipales e 
indicadores financieros de las empresas de la industria extractiva. En la evaluación se aplicó el método integrado y se calculó el índice de desempeño de los territorios del clúster identificados en una escala de diez puntos. Las zonas identificadas se clasificaron por recursos y potencial de producción. Se calculó el índice de rendimiento general de la zona de conglomerados. Pareció factible agrupar la industria extractiva en la región estudiada, ya que puede aumentar la competitividad de las empresas locales y contribuir al desarrollo socioeconómico de sus distritos municipales. El método propuesto se puede aplicar para una evaluación integral del sector de uso del subsuelo en los territorios del norte.

Palabras clave: organización espacial, agrupamiento, uso del subsuelo, metodología de evaluación, calificación, región norte.

\section{INTRODUCTION}

In Russia, the resource-based industry of northern regions focusing on subsoil use has developed in a historical manner, including over a long period of planned national economy. The huge costs associated with the exploration and reclamation of remote northern areas were compensated by the cross-subsidy mechanisms embracing the entire country. Among other things, it ensured the economic clustering of the regions, large industrial areas, industries and enterprises involved in the reproduction of the aggregate added value. It should be noted that the existing manufacturing and production clusters function rather effectively in modern conditions. Nevertheless, in the northern regions, in the absence of nationwide cross-subsidy mechanisms, the economic efficiency of subsoil use naturally decreased due to insufficient involvement in the value chains. In this regard, it is relevant to study the optimal spatial organization of productive forces (including clusters) and endeavor to improve the accuracy of assessment of the production potential of economic sectors.

The purpose of this work is to make a comprehensive assessment of the feasibility of cluster organization of the subsoil use sector, in the Republic of Sakha (Yakutia), the Russian Federation, factoring in the existing and prospective economic zoning and the existing potential. The study used statistical data on the municipal districts (Federal State Statistic Service 2019, 2020) and financial indicators of the extractive industry companies.

The market relations emerging in Russia in the late 20th and early 21 st centuries brought about new trends in the development of regional economies within the country. There appeared new forms of production relations between economic structures consisting of competing large companies. The emergent geo-economic market system acquired an expanded capacity in the domestic market coupled with the access to international markets. Economic entities could decide how to move goods, capital, services and labor, regardless of the interests of local authorities, and establish numerous distributive and cooperative ties. Ultimately, the economic system of subsoil use underwent a transformation not only in relation to the national and regional economies, but also in relation to the global economic space.

The spatial development of extractive industries in a particular region primarily comes from the local availability of mineral and fuel-and-energy resources. Consequently, it is the mineral raw material and fuel-and-energy potentials, being the foundation of the extractive economy, that determine the spatial system of subsoil use.

Earlier, extractive facilities in the Republic of Sakha (Yakutia) (henceforth the RS(Ya)) were placed and commissioned depending on the preparedness for the exploitation of certain deposits and the demand for the mineral resource in the national economy and in the world. Today, the industrial, social, transport, etc. infrastructure that formed around the mined deposits and producing fields no longer meets all modern requirements for sustainable development of territories, industrial areas and economic zones. This circumstance can be aggravated by non-optimal (for modern conditions) economic zoning, which hinders the accuracy of comprehensive assessments of the prospects for optimizing the spatial organization of regional economies and the accuracy of assessments of the feasibility of clustering subsoil users, including when developing new fields. 
To elaborate new zoning systems in the conditions of a northern region, it is advisable to take into account the significant asymmetry of the spatial development of socio-economic systems at various levels.

Within the framework of this study, when conducting the comprehensive assessment of the feasibility of cluster organization of subsoil users in the RS(Ya), the following main factors that affect the development prospects were identified:

- $\quad$ asymmetry of the spatial development of socio-economic systems at various levels;

- $\quad$ zoning systems;

- $\quad$ mineral and production potentials.

\section{LITERATURE OVERVIEW}

Many researchers addressed the problem of uneven spatial development of regions in different years. Unlike the economies of Europe and North America, Russia's market economy, founded on the Soviet planned economy that had been uniformly developed in the entire country, went through many changes. In this regard, A.I. Treyvish (2019) thinks that the unevenness and the structural diversity of the spatial development of the national economy are scientific problems just as much Russia-specific realities, and A.M. Okun (1975) claims that the pursuit of equality entails heavy penalties in terms of reduced economic effect.

S.V. Bereznev and E.E. Kulpina (2018) and I.T. Shagiyeva (2013) addressed the problems of regional development and examined the theories of economic growth and development. I.V. Naumov, V.M. Sedelnikov and L.M. Averina (2020) made a good review of a large body of literature on the theoretical aspects of spatial organization of territorial development.

The evolution of concepts and models of spatial development of socio-economic processes can be traced in the works by A. Weber (1926), T. Palander (1935), A. Lösch (2007), G. Murdal (1957), W. Isard (1960), M. Fujita and P. Krugman (1995) and other authors.

Clustering can be called a new form of spatial organization of economic activity. M. Porter (1993), M.G. Enright (1993), P.Krugman (1995) and S.A. Rosenfeld (1997) devoted their studies to the cluster theory. Recently, the concept of 'smart specialization' formulated by D.Forey, P. David and B. Hall (2009) has developed in the field of cluster economics.

Logically, the spatial development of regions depends on the location of deposits, mainly those of highly liquid, export-oriented, high value added, investment-attractive minerals. For the RS(Ya), the major budget revenue generating sectors are oil and gas, diamond, gold and coal extraction, located in the south and the west of the region. Y.A. Kolomak et al. (2018) highlighted the need to move from localized centers of mineral resources extraction to spatially distributed value chains that generate value and deliver socio-economic effects. E.I. Efremov et al. (2016a) addresses modern problems of the spatial organization of subsoil use in the RS(Ya), including methodological approaches, various methods of the spatial differentiation analysis, and the typology of districts.

In their study of the role of investments in the economy of Russia's Far East, Minakir and Prokapalo (2018) point to two fundamental factors of the economic development of that region: 'the volume of investments (both generated in the region and redistributed in its favor from the inter-regional system) and the nature of institutions that determine the possibilities of forming internal and external development resources and their most efficient use.'

Egorov, Babkin and Kovrov (2015), Efremov et al. (2016b), and Efremov et al. (2017) suggested clustering for the resource-oriented economy of the RS(Ya), capable of creating conditions for concentration and cooperation of the productive potential of subsoil users, and proposed a 
methodological approach to assessing regional industrial clusters. They pointed to three promising territories: the Southern Yakutia with huge reserves of coal, apatite, iron ore, and gold; the Western Yakutia with its oil, natural gas, and water resources; and the Arctic Yakutia with vast fuel and energy resources (oil, natural gas, coal, natural bitumen, etc.), and non-ferrous metals, including gold, tin, silver, and aluminum deposits already explored and prepared for exploitation.

Having studied Russia's clusters, Y.E. Kolchinskaya, L.E. Limonov and Y.S. Stepanova (2019) concluded that 'Russian industrial enterprises operate more efficiently in clusters than separately, although such difference in efficiency is rather small. These results do not completely correlate with foreign ones where researchers usually note more pronounced effects.'

It should be noted that the problem under consideration is not new, since maintaining the necessary territorial proportions in the economy, thus preventing excessive socio-economic differentiation of regions has always been an important task for the government. In Russia, the transition to market conditions has only aggravated the intraregional asymmetry, and this is one of the most negative outcomes of the market reforms.

The asymmetry manifests itself at all levels of administrative-political and economic subdivision, from the uneven development of federal districts, large economic regions and individual constituents of the Russian Federation to the uneven development of municipalities (administrative districts) within oblasts, krais and republics.

The implementation of an effective regional policy is hampered by the fact that Russia's regions are fundamentally different from each other in terms of economic potential, fiscal capacity, and budgetary security. In a federal state with a market economy, the amount of financial resources created at the regional budget level should be sufficient for the development and modernization of the regional infrastructure, and for the performance of requirements to authorities arising from current legislation. Modern Russia derived its federative status from the previous administrative-territorial division that in no way catered to the concerns of self-sufficiency in the regions.

The main aspects of the intraregional asymmetry are the following:

- the intraregional asymmetry aggravated following the general economic trends that occurred in the country in the 1990s, in particular, the de-industrialization of certain territories, the growth of unemployment, and the impoverishment of the population. This aspect in itself can be a topic for research. Meanwhile, it should be noted that a proponent reason for the strengthening of socioeconomic differentiation was the entrenched dissimilar capabilities of administrative-territorial constituents to adapt to the emerging market economy due to the impact of combined national trends and specific local factors;

- the other aspect is related to the possibility of measuring intraregional asymmetry. Our analysis of recent domestic publications has shown that to the present day, researchers resort to a fairly limited number of methods for the quantitative assessment of intraregional asymmetry. The most frequently used ones are the range of difference and the deviation from mean (dispersion, variation, average deviation, etc.). In general, it is rather difficult to form a set of statistical indicators that would systematically characterize the main aspects of intraregional relations;

- the assessment of the multifaceted effects of aggravated intraregional asymmetry. First, the strengthening of socio-economic differentiation incurred asymmetric shifts in the investment allocation in the regional economies alongside the investment slump. Another consequence was the population redistribution from rural areas to urban settlements.

In the RS(Ya), intraregional asymmetry was caused, in addition to general climatic and geographical factors, by the territorial distribution of the extractive industries. Here, competitive are the deposits of commercially advantageous minerals, i.e. the mineral raw materials and the fuel-and-energy resources that are in demand and have a high market value, and have access to the infrastructure. In terms of the territorial aspect, the subsoil users in the RS(Ya) are actively exploiting the diamond deposits and oil 
and gas fields of the Western Yakutia; the coal and gold ore deposits of the Southern Yakutia; and the gold placers of the Eastern Yakutia. These mineral deposits are highly viable in the domestic and global markets.

The problem of comprehensive and efficient use of natural resources in relation to each region may be relevant in its own way, depending on how strongly the natural resources affect its socio-economic sustainability. For those regions where extraction of natural resources is prioritized, the regional authorities should take such actions that will make the region well developed in this regard. By contrast, for the federal subject where the extraction of natural resources or the use of a favorable economic and geographical location is not the main generator of profit, this problem may be of low priority. P. De Sa (2019) showed that centralized management and contradictory legal and institutional arrangements, especially the relation between the mining and the environmental authorities, can create tensions between central governments and regional authorities. The researcher proposed that mining legislation must be harmonized with other sectors and adapted to territorial management. This requires participatory approaches to define integrated legal and institutional frameworks to manage the territories' natural resources in the context of coherent decentralization processes. It also calls for the aligned intervention of different levels of government using the Municipality as the relevant coordination space.

The concept of subsoil use covers not only extraction, processing, use and sale of natural resources at domestic and foreign markets, but also institutional, economic, organizational, environmental and social aspects. Governments and non-governmental organizations can be inclined to view the resource sector with some cynicism. Junior mining companies sometimes engage with local communities, leave without a trace (or perhaps with tracks, trails and trenches) and offer only a brief hope for betterment causing strong emotive reactions (Gourley, 2019). Consequently, while developing the subsoil use sector, the region has to develop mining industries, manufacturing and processing facilities, social assets and human recourses, research facilities and educational institutions, and various service industries, ranging from shipping and logistics to sales and distribution. In the future, this structural system can lay the foundation for an extractive cluster as a form of the spatial extractive economy.

\section{MATERIALS AND METHODS}

The proposed procedure for studying the spatial organization of extractive economy in the context of growing market asymmetry includes three steps presented in Table 1.

Table 1. Procedure for studying the spatial organization of extractive economy in the context of growing market asymmetry.

\begin{tabular}{|c|c|c|}
\hline Step 1 & $\begin{array}{l}\text { Review and adaptation of the } \\
\text { methodological approach to the study of } \\
\text { the spatial organization of the regional } \\
\text { extractive economy in the context of } \\
\text { growing market asymmetry }\end{array}$ & $\begin{array}{l}\text { Theoretical and practical issues of market } \\
\text { asymmetry in the regional extractive industries } \\
\text { Foundations of the spatial organization of } \\
\text { extractive economy } \\
\text { Development of methodological approaches to } \\
\text { the study of the spatial organization of the } \\
\text { regional extractive economy in the context of } \\
\text { growing market asymmetry }\end{array}$ \\
\hline Step 2 & $\begin{array}{l}\text { Spatial differentiation of the basic } \\
\text { extractive industries in the } \mathrm{RS}(\mathrm{Ya})\end{array}$ & $\begin{array}{l}\text { Methodology and technique of spatial } \\
\text { differentiation of the extractive industries } \\
\text { Study of the potential of the mineral raw } \\
\text { material base and the production facilities of the } \\
\text { extractive industries in the RS(Ya) } \\
\text { Territorial zoning based on the cluster } \\
\text { organization of the extractive industries }\end{array}$ \\
\hline Step 3 & $\begin{array}{l}\text { Evaluation of the long-term prospects for } \\
\text { development and spatial differentiation } \\
\text { of the extractive economy in the RS(Ya) }\end{array}$ & $\begin{array}{l}\text { Comprehensive assessment of the effectiveness } \\
\text { of development and placement of the spatial } \\
\text { organization of the extractive industries }\end{array}$ \\
\hline
\end{tabular}


A generally accepted approach to identifying clusters is the analysis of production efficiency, based on quantitative assessment methods, since it gives a blueprint of a potential cluster and points to the presence of various industries in the studied region.

Having assessed the mineral resources potential and the production facilities, and having factored in the trend for changing criterial indicators of the spatial differentiation of the basic extractive industries (diamond, oil-and-gas, gold and coal extraction), we identified four cluster zones within the RS(Ya): Western, Southern, Eastern and Arctic (Fig. 1). The four zones form an annular territorial system, covering all the main economic-forming segments of the RS(Ya)'s economy. Such arrangement of the basic extractive industries appears to create a favorable condition for the rational formation of the productive and social infrastructures that can serve as foundations for territorial-industrial clusters (Gulyaev et al., 2019).

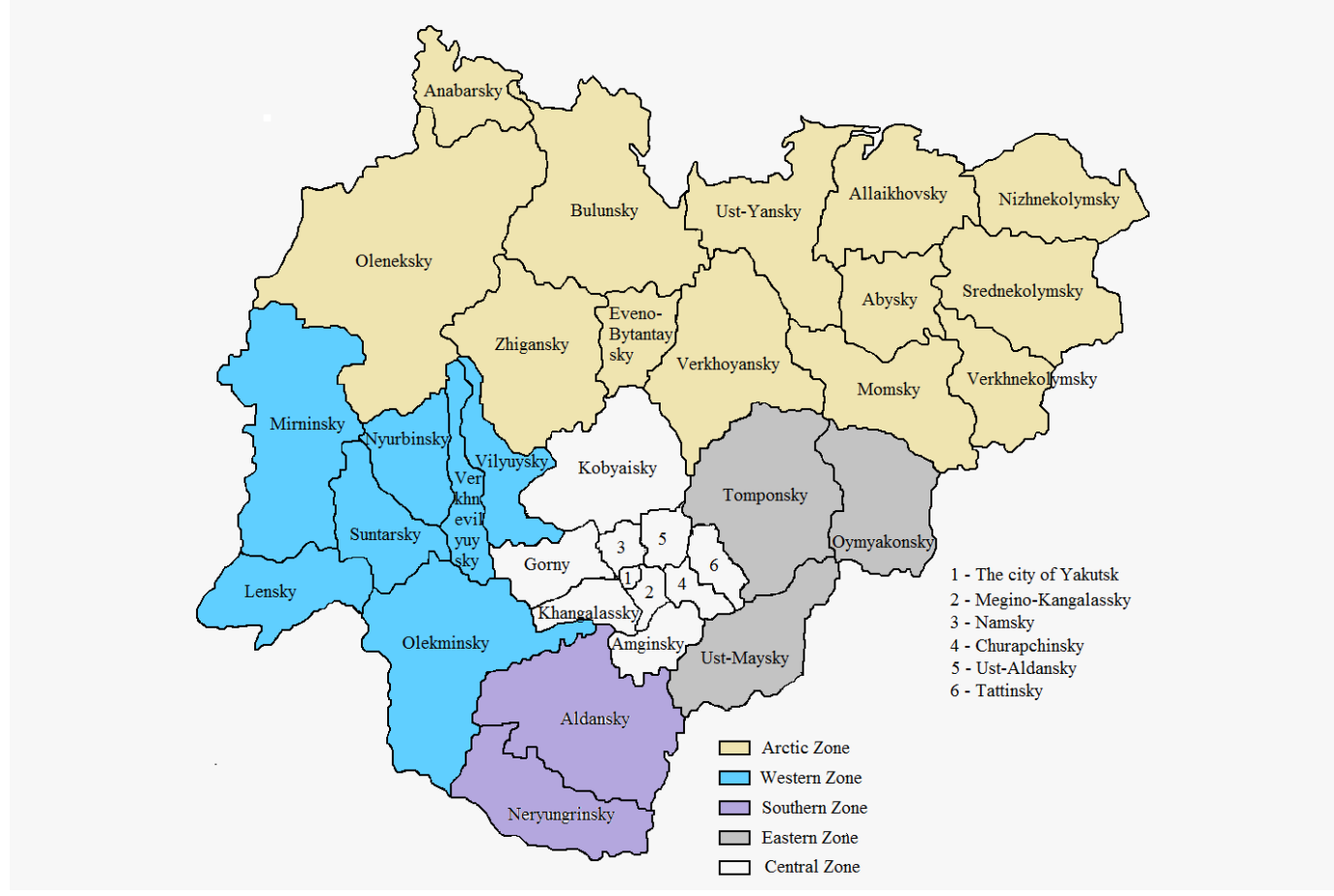

Figure 1. Zoning of the cluster organization of the extractive industries in the RS(Ya).

It was also necessary to address the economic performance of the municipal districts in which the clusters and the principal subsoil users are located. The main cluster constituents in the identified zones are diamond, oil-and-gas, gold and coal extraction companies, the transport infrastructure, and the power supply networks (Table 2).

Table 2. Main cluster constituents in the subsoil use sector of the RS(Ya)

\begin{tabular}{|c|c|c|c|}
\hline $\begin{array}{l}\text { Cluster territory and } \\
\text { municipal districts }\end{array}$ & $\begin{array}{c}\text { Cluster kernel } \\
\text { (principal subsoil users) }\end{array}$ & Core activity & $\begin{array}{c}\text { Transport and power } \\
\text { supply availability }\end{array}$ \\
\hline $\begin{array}{c}\text { Arctic Zone } \\
\text { (Abysky, Anabarsky, } \\
\text { Bulunsky, } \\
\text { Verkhnekolymsky, }\end{array}$ & $\begin{array}{c}\text { Alrosa PJSC, } \\
\text { Almazy Anabara JSC } \\
\text { Arctic Capital LLC }\end{array}$ & $\begin{array}{l}\text { diamond mining } \\
\text { gold mining }\end{array}$ & $\begin{array}{l}\text { Northern Sea Route, } \\
\text { winter snow roads, } \\
\text { river transport, }\end{array}$ \\
\hline
\end{tabular}




\begin{tabular}{|c|c|c|c|}
\hline $\begin{array}{l}\text { Verkhoyansky, Momsky, } \\
\text { Oleneksky, } \\
\text { Srednekolymsky, and }\end{array}$ & Zyryansky Ugolny Razrez JSC & coal mining & \\
\hline \multirow{3}{*}{$\begin{array}{c}\text { Eastern Zone } \\
\text { (Tomponsky, } \\
\text { Ust-Maysky and } \\
\text { Oymyakonsky Districts) }\end{array}$} & $\begin{array}{l}\text { GRK Zapadnaya JSC, } \\
\text { Poisk Zoloto JSC }\end{array}$ & gold mining & \multirow{3}{*}{$\begin{array}{l}\text { R504 Kolyma Highway, } \\
\text { winter snow roads, } \\
\text { river transport }\end{array}$} \\
\hline & $\begin{array}{c}\text { Sarylakh Surma JSC, } \\
\text { Zvezda LLC }\end{array}$ & $\begin{array}{l}\text { pre-production } \\
\text { gold mining }\end{array}$ & \\
\hline & $\begin{array}{l}\text { Shakhta Dzhebariki Khaya } \\
\text { OJSC (Yakutugol OJSHC) }\end{array}$ & coal mining & \\
\hline \multirow{4}{*}{$\begin{array}{c}\text { Western Zone } \\
\text { (Verkhnevilyuysky, } \\
\text { Vilyuysky, Lensky, } \\
\text { Mirninsky, Nyurbinsky, } \\
\text { Olekminsky and } \\
\text { Suntarsky Districts) }\end{array}$} & $\begin{array}{c}\text { Alrosa PJSC, } \\
\text { Alrosa Nyurba PJSC }\end{array}$ & diamond mining & \multirow{4}{*}{$\begin{array}{l}\text { A331 Vilyuy Highway } \\
\text { winter snow roads, } \\
\text { river transport, Cascade } \\
\text { of Vilyuyskaya, } \\
\text { Mirninskaya and } \\
\text { Svetlinskaya HPPs }\end{array}$} \\
\hline & $\begin{array}{c}\text { Surgutneftegas PJSC, } \\
\text { Taas Yuryakh } \\
\text { Neftegazodovycha LLC }\end{array}$ & $\begin{array}{l}\text { oil and gas } \\
\text { extraction }\end{array}$ & \\
\hline & Suntartseolit LLC & $\begin{array}{l}\text { coal mining } \\
\text { zeolite mining }\end{array}$ & \\
\hline & YATEK PJSC & $\begin{array}{l}\text { gas extraction } \\
\text { and natural gas } \\
\text { liquid production }\end{array}$ & \\
\hline \multirow{2}{*}{$\begin{array}{c}\text { Southern Zone } \\
\text { (Aldansky and } \\
\text { Neryungrinsky Districts) }\end{array}$} & $\begin{array}{l}\text { Denisovsky and Inaglinsky } \\
\text { MPPs (CC Kolmar LLC), } \\
\text { Yakutugol OJSHC }\end{array}$ & coal mining & \multirow{2}{*}{$\begin{array}{l}\text { A360 Lena Highway, } \\
\text { Berkakit-Tommot- } \\
\text { Yakutsk Railway, } \\
\text { Chulmanskaya CHP, } \\
\text { Neryungrinskaya HPP }\end{array}$} \\
\hline & $\begin{array}{l}\text { Polyus Aldan CJSC, } \\
\text { Seligdar PJSC }\end{array}$ & gold mining & \\
\hline
\end{tabular}

To evaluate performance, the integrated assessment on a 10-point scale was applied according to Formula 1 (Gulyaev et al. 2019):

$$
I_{\text {efMD }}=\left(\sum_{i=1}^{N} K_{i}\right) / N
$$

where $I_{\text {efMD }}$ is the economic performance index of the municipal district; $K_{i}$ is the proportional factor calculated on the basis of the main financial and economic statistical indicators of the municipal district, $0 \leq K_{i} \leq 1$ (Federal State Statistic Service 2019a, 2019b); and $N$ is the number of municipal districts in the $\mathrm{RS}(\mathrm{Ya})$.

Normalizing Formula 2 was used in the calculations to bring the heterogeneous statistical indicators to a uniform measurement system:

$$
K_{i}=\frac{\mu_{i}-\min \mu_{i}}{\max \mu_{i}-\min \mu_{i}}
$$

where $\mu_{i}$ stands for the statistical indicators of the municipal district.

The selected statistical indicators for 2015-2018 that characterize the object of study (the annual average) are given in Table 3 . 
Table 3. Relative statistical indicators $K_{i}$ for assessing the economic performance of the RS(Ya) municipal districts.

\begin{tabular}{|c|c|c|}
\hline$K_{i}$ & Proportional factor & Description \\
\hline$K_{l}$ & Per capita production & $\begin{array}{l}\text { Volume of shipped goods of own production / Population } \\
\text { size }\end{array}$ \\
\hline$\kappa_{2}$ & Labor productivity & $\begin{array}{l}\text { Volume of shipped goods of own production / Average } \\
\text { number of employees }\end{array}$ \\
\hline$K_{3}$ & Capital intensity & $\begin{array}{l}\text { Fixed assets value / Volume of shipped goods of own } \\
\text { production }\end{array}$ \\
\hline$K_{4}$ & $\begin{array}{l}\text { Average annual turnover of } \\
\text { companies }\end{array}$ & Total annual turnover / Number of companies \\
\hline$\kappa_{5}$ & $\begin{array}{l}\text { Proportion of profitable } \\
\text { companies }\end{array}$ & --- \\
\hline
\end{tabular}

\section{RESULTS}

The calculations of economic performance in 35 municipal districts by Formulas 1 and 2 revealed that Lensky, Mirninsky and Nyurbinsky Districts of the Western Zone had the best economic performance by the $I_{e f M D}$ index. The ratings were low for Ust-Yansky and Eveno-Bytantaysky Districts of the Arctic Zone and the centrally located Khangalassky and Churapchinsky Districts (Table 4).

\begin{tabular}{clcccc}
\multicolumn{5}{c}{ Table } & . Economic performance of the RS(Ya) municipal districts in 2015-2018 by the $I_{e f \text { MP }}$ index. \\
\hline Line & \multicolumn{1}{c}{ Municipal district } & 2015 & 2016 & 2017 & 2018 \\
1 & Abysky & 2.48 & 0.40 & 0.33 & 3.62 \\
2 & Aldansky & 3.83 & 2.14 & 1.90 & 5.09 \\
3 & Allaikhovsky & 2.99 & 0.22 & 0.28 & 1.42 \\
4 & Amginsky & 3.23 & 0.41 & 0.06 & 2.19 \\
5 & Anabarsky & 6.64 & 1.55 & 1.74 & 2.71 \\
6 & Bulunsky & 2.67 & 1.17 & 0.58 & 4.41 \\
7 & Churapchinsky & 3.27 & 0.31 & 0.10 & 3.54 \\
8 & Eveno-Bytantaysky & 2.64 & 0.00 & 0.03 & 2.59 \\
9 & Gorny & 3.98 & 0.76 & 0.25 & 0.73 \\
10 & Khangalassky & 1.63 & 0.26 & 0.16 & 2.99 \\
11 & Kobyaisky & 0.00 & 0.04 & 0.05 & 2.74 \\
12 & Lensky & 10.0 & 10.0 & 10.0 & 10.0 \\
13 & Megino-Kangalassky & 2.55 & 0.38 & 0.10 & 2.42 \\
14 & Mirninsky & 7.35 & 7.62 & 6.56 & 7.92 \\
15 & Momsky & 0.26 & 0.07 & 0.15 & 2.63 \\
16 & Namsky & 1.64 & 0.34 & 0.10 & 3.57 \\
17 & Neryungrinsky & 2.73 & 2.30 & 2.69 & 4.56 \\
\hline
\end{tabular}




\begin{tabular}{llllll}
\hline 18 & Nizhnekolymsky & 1.69 & 0.10 & 0.05 & 1.22 \\
19 & Nyurbinsky & 6.59 & 7.07 & 6.59 & 5.83 \\
20 & Olekminsky & 3.39 & 1.35 & 1.21 & 3.70 \\
21 & Oleneksky & 2.46 & 0.18 & 0.07 & 2.76 \\
22 & Oymyakonsky & 3.81 & 3.30 & 4.02 & 3.93 \\
23 & Srednekolymsky & 2.22 & 0.12 & 0.15 & 2.76 \\
24 & Suntarsky & 2.00 & 0.45 & 3.40 & 3.41 \\
25 & Tattinsky & 2.67 & 0.42 & 0.10 & 3.00 \\
26 & Tomponsky & 4.19 & 7.18 & 0.76 & 3.75 \\
27 & Ust-Aldansky & 3.38 & 0.23 & 0.02 & 3.08 \\
28 & Ust-Maysky & 1.92 & 0.51 & 1.07 & 2.61 \\
29 & Ust-Yansky & 3.59 & 0.28 & 0.34 & 1.06 \\
30 & Verkhnevilyuysky & 1.73 & 0.18 & 0.00 & 1.92 \\
31 & Verkhnekolymsky & 2.81 & 0.31 & 0.22 & 2.98 \\
32 & Verkhoyansky & 2.23 & 0.17 & 0.26 & 2.80 \\
33 & Vilyuysky & 3.39 & 1.02 & 1.36 & 3.32 \\
34 & Zhigansky & 3.28 & 0.14 & 0.13 & 0.00 \\
35 & The city of Yakutsk & 2.63 & 0.72 & 1.18 & 2.76 \\
\hline & & & & &. \\
\hline
\end{tabular}

Lensky, Mirninsky and Nyurbinsky Districts of the Western Zone, with its diamond mining industry, and Anabarsky District of the Arctic Zone topped the rating by the average value of the economic performance index $I_{\text {ef } M D}$ for the studied years. Lensky Disctrict is the ten-score leader because it is the center of the republic's oil and gas production. Its two large fields Talakanskoye and Chayandinskoye feed the export-oriented trunk pipelines: the Eastern Siberia - Pacific Ocean oil pipeline and the Power of Siberia gas pipeline.

Also, Tomponsky and Oymyakonsky Districts of the Eastern Zone, Neryungrinsky and Aldansky Districts of the Southern Zone, and Olekminsky District of the Western Zone, where the extractive coal and gold ore industries are located, had the rating above the RS(Ya)'s average (Fig. 2).

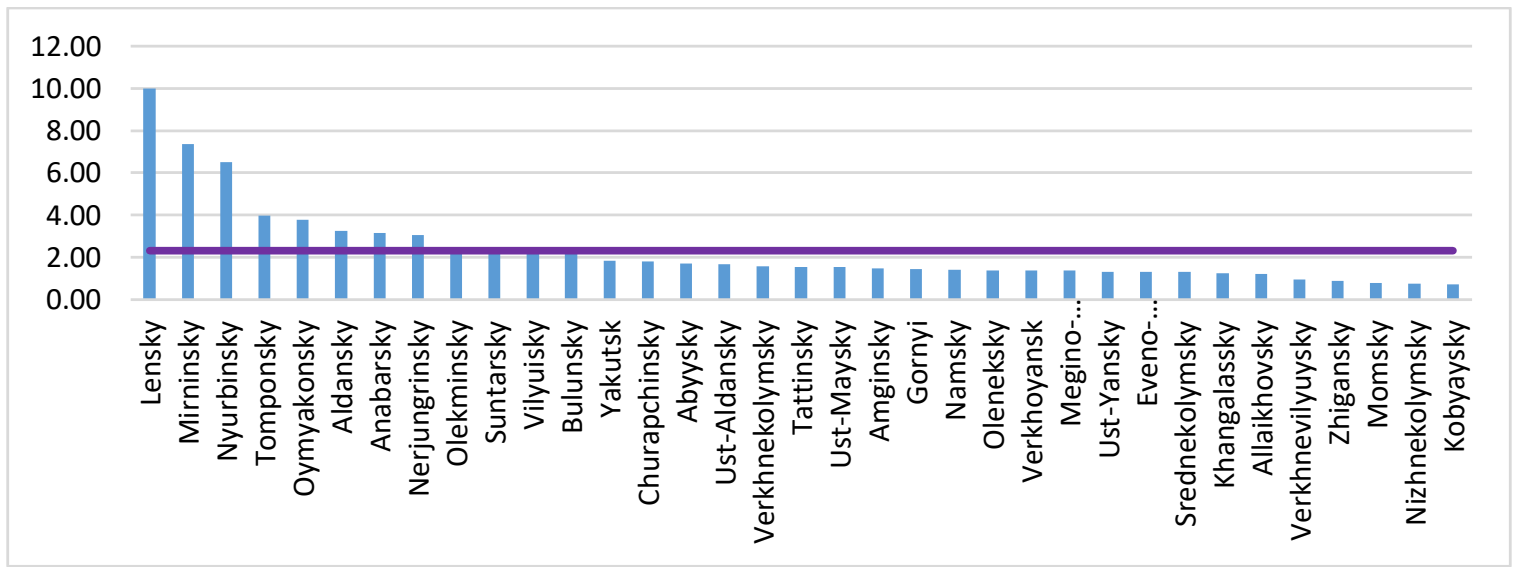

Figure 2. Average economic performance of the RS(Ya) municipal districts in 2015-2018 by the $\mathrm{I}_{\mathrm{efMD}}$ index. 
The main share of gold production (over 90\%) in the republic is carried out in Aldansky and Oymyakonsky Districts, and coal is mined in Neryungrinsky District. The Neryungri coal is exported to the countries of the Asia-Pacific region. In recent years, gold mining began at the Gross and Tabornoye ore deposits in Olekminsky District, which also has iron ores deposits.

Fig. 3 shows the dynamics of the economic performance of the four cluster zones in the RS(Ya) in 2015-2018 by the $I_{e f M D}$ index. There was an overall slight increase in economic performance, with the Western Zone leading and the Arctic Zone falling behind.

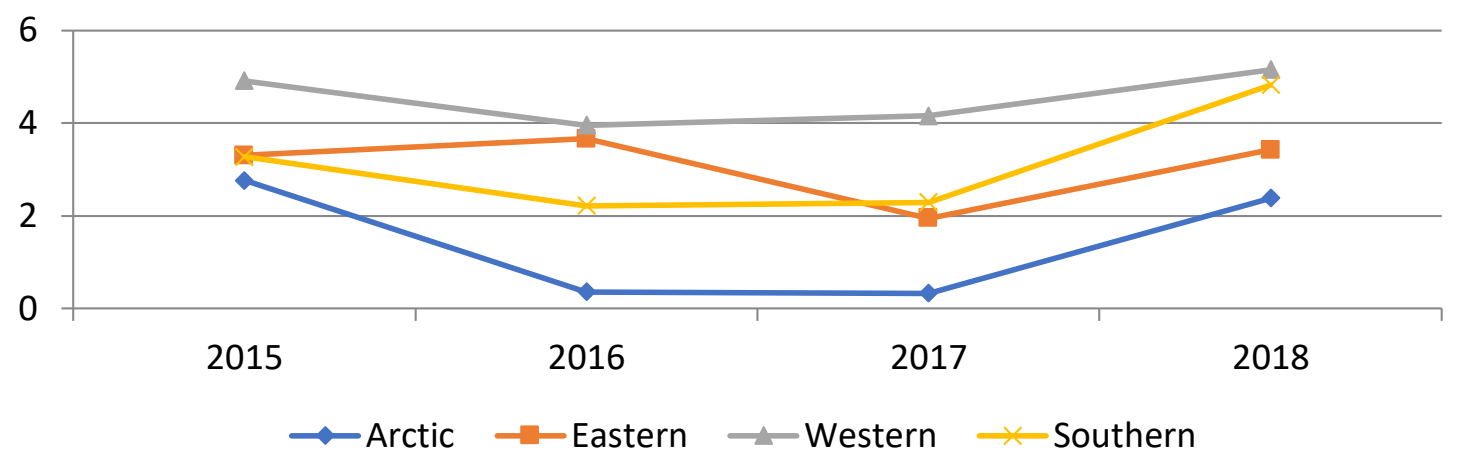

Figure 3. Economic performance of the RS(Ya) municipal districts grouped by cluster zones, in 2015-2018 by the $\mathrm{I}_{\mathrm{efMD}}$ index.

To assess the performance of the cluster kernel companies (principal subsoil users), we calculated the corporate efficiency index $\left(I_{\text {efCor }}\right)$ that was determined by the ratio of the company's share in the total profit of the cluster kernel companies to the company's share in their total costs (Table 5). This index characterized the relative performance of the cluster participants (Shutilov, 2013):

$$
I_{\text {efCor }}=\frac{P_{i} / \sum_{i=1}^{M n} P_{i}}{Z_{i} / \sum_{i=1}^{n} z_{i}}
$$

where $P_{i}$ stands for the profit of the company; $Z_{i}$ stands for the costs of the company; and $n$ is the number of cluster zones.

Table 5. Corporate efficiency indices $\left(I_{\text {efCor }}\right)$ of the cluster kernel companies grouped by cluster zones, in $2015-$

\begin{tabular}{lcccc}
\multicolumn{1}{c}{ Company } & 2018. & & & \\
\hline & 2015 & 2016 & 2017 & 2018 \\
\hline Western Zone & 0.98 & 0.8 & 0.84 & 0.95 \\
Surgutneftegas PJSC & 45.1 & 68.92 & 67.73 & 32.5 \\
Alrosa PJSC & 0.32 & 1.00 & 0.53 & 0.26 \\
YATEK PJSC & 0.07 & 0.69 & 0.27 & 0.11 \\
Suntartseolit LLC & 0.01 & 0.96 & 2.42 & 1.78 \\
Taas Yuryakh Neftegazodobycha LLC & 0.60 & 3.51 & 2.44 & 0.81 \\
Alrosa Nyurba PJSC & & & & \\
Southern Zone & 0.00 & 0.02 & 0.18 & -0.18 \\
Seligdar PJSC & 6.01 & 6.57 & 8.72 & 12.22 \\
Polyus Aldan CJSC (Polyus Zoloto) & 0.01 & 0.01 & 0.02 & 0.17 \\
Denisovsky MPP (CC Kolmar LLC) & 0.00 & 0.01 & 0.11 & 0.17 \\
Inaglinsky MPP (CC Kolmar LLC) & & & & \\
Arctic Zone & & & & \\
\hline
\end{tabular}




\begin{tabular}{lcccc}
\hline \multicolumn{1}{c}{ Company } & 2015 & 2016 & 2017 & 2018 \\
\hline Arctic Capital LLC & 0.00 & 0.00 & 0.18 & 2.20 \\
Almazy Anabara JSC & 1.01 & 0.99 & 1.01 & 0.98 \\
Zyryansky Ugolny Razrez JSC & 0.76 & 1.45 & 0.65 & 0.93 \\
Eastern Zone & & & & \\
Zapadnaya Gold Mining Limited & 0.73 & 1.67 & 2.32 & 1.32 \\
Poisk Zoloto JSC & 1.30 & 0.62 & 0.5 & 0.64 \\
Sarylakh Surma JSC & 1.39 & 0.32 & 0.26 & 0.63 \\
Zvezda LLC & 0.67 & 0.06 & 0.29 & 0.25 \\
\hline
\end{tabular}

Source: Calculated based on data from https://www.audit-it.ru/audit/

In the rating by the corporate efficiency index $\left(I_{\text {efCor }}\right)$, companies in the Western Zone led noticeably, while companies in the other zones had similar modest results (Fig. 4).

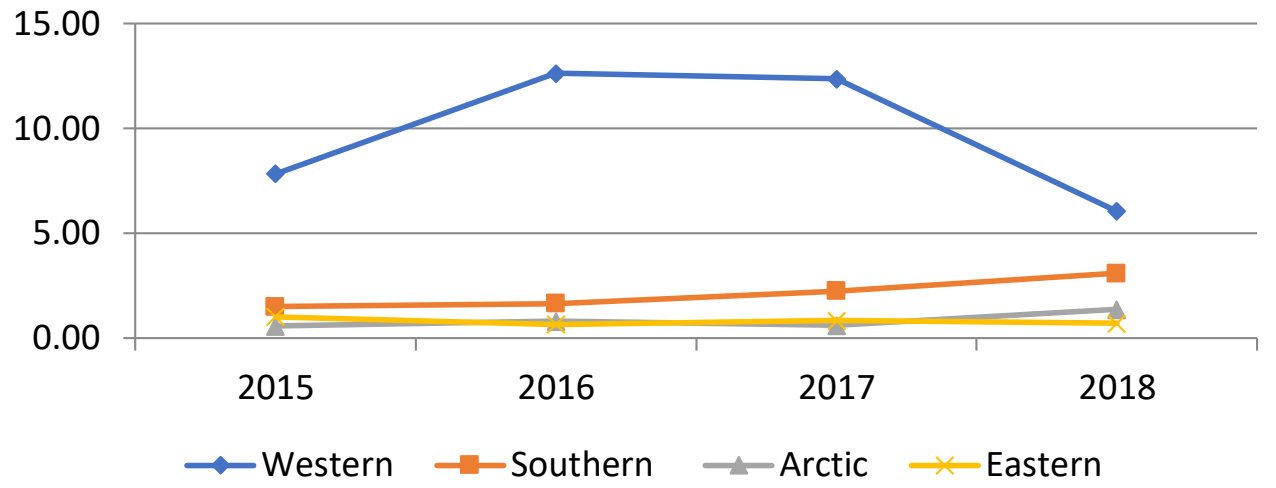

Figure 4. Economic performance of the principal subsoil users grouped by cluster zones, in 2015-2018 by the $\mathrm{I}_{\text {efCor }}$ index.

To summarize the assessment, we suggest to apply the general cluster zone performance index $I_{\text {efCl }}$ based on the average value of the calculated resource and productive potential $I_{\text {pot }}$, the economic performance of the municipal districts $I_{e f M D}$, and the corporate efficiency indices of the principal subsoil users in the cluster zones $I_{\text {efCor }}$. The general cluster zone performance index was calculated by formula:

$$
I_{e f K L}=\left(I_{p o t}+I_{e f M D}+I_{e f C o r}\right.
$$

where $n$ is the number of studied indices.

To make the comprehensive assessment of the cluster zones' performance, we took the final comprehensive potential $I_{\text {pot }}$ (Nikiforova, 2020); refer to Fig. 5 . 


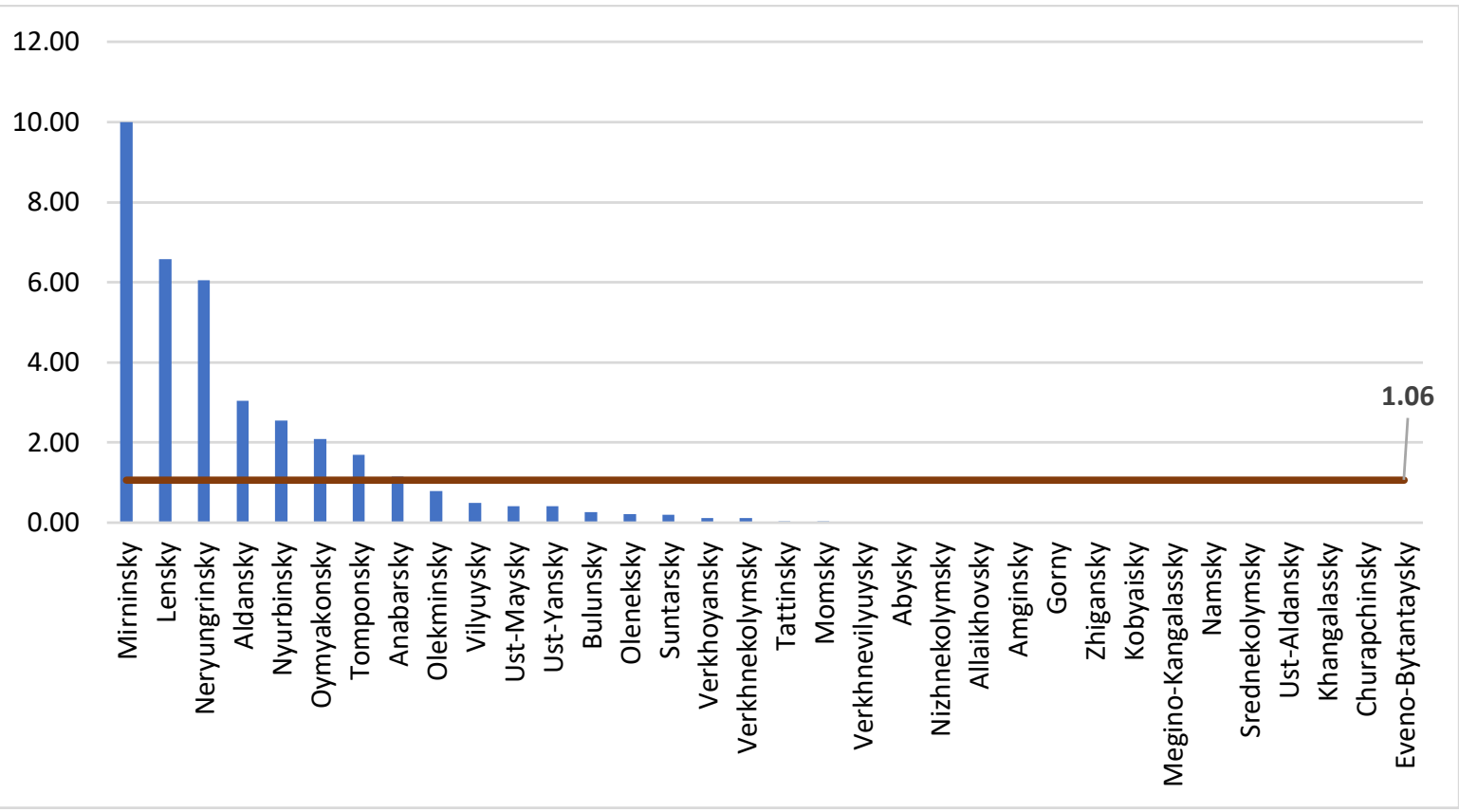

Figure 5. Assessment of the final comprehensive potential ( $\left.\mathrm{I}_{\text {pot }}\right)$ of the basic extractive industries in the RS(Ya) municipal districts in 2015-2018 (in points).

The results of the comprehensive assessment, calculated by Formula 4, proved the feasibility of creating territorial-industrial clusters in the Western, Southern, Eastern and Arctic Zones of the $\mathrm{RS}(\mathrm{Ya})$. The Western zone with its diamond mining and oil and gas extraction industries, and the Southern Zone, with its coal and gold deposits, promise to be the most efficient in terms of clustering (Fig. 6).

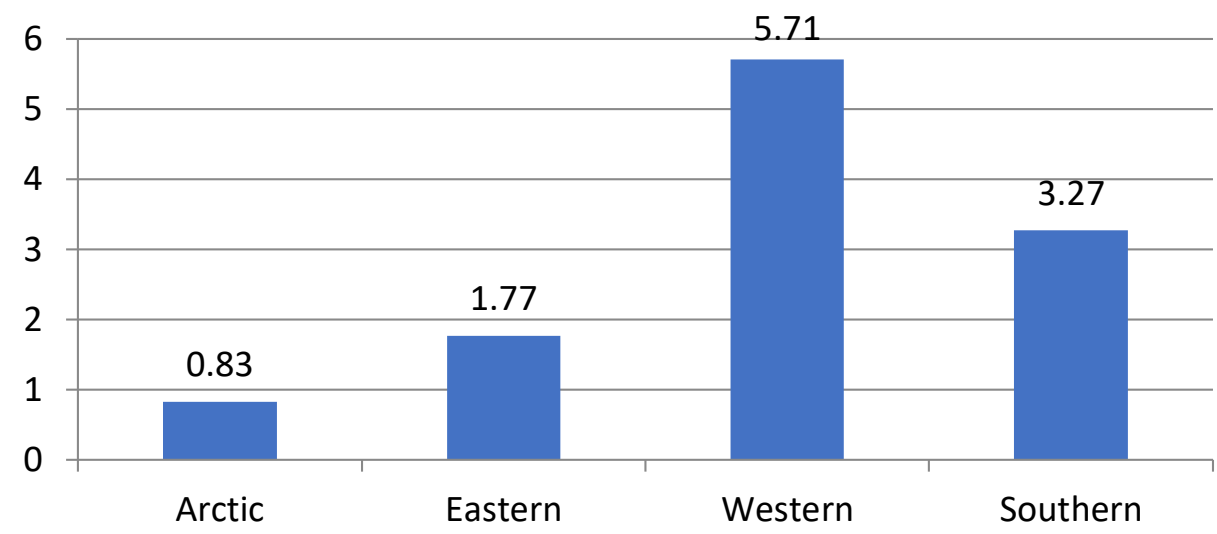

Figure 6. General performance index $\mathrm{I}_{\mathrm{efCl}}$ of the cluster zones.

\section{DISCUSSION}

The long-term outlook on the development potential and the spatial differentiation of the extractive economy in the $\mathrm{RS}(\mathrm{Ya})$ is based on the comprehensive assessment of the development and distribution of extractive industries facilities. Since the main budget-forming sectors of subsoil use are diamond, oil and gas, coal and gold extraction, in the territorial aspect the advantage belongs to the municipal districts where these types of operations are conducted. In this regard, the Western and Southern Zones with the most equipped infrastructure appear to be more competitive. 
The Western Zone has large companies with available infrastructure, from transportation to sale of finished goods, such as ALROSA (diamond mining), Surgutneftegas, Gazprom (oil and gas) and others (Antonov et al., 2019).

The Southern Zone specializes mainly in the extraction of coal and gold. The large subsoil users are Polyus Aldan, Seligdar (gold), Kolmar, Mechel (coal) and others. By 2022, Kolmar plans to increase coal production at the Inaglinsky Mining and Processing Plant to 15.4 million tons and at the Denisovskaya Mine to 4 million tons, thus making itself one of the five largest coal enterprises in Russia (Kolmar Coal Mining Company, 2020). The Elginsky coking coal complex is also located in the south of the RS(Ya).

In the Eastern Zone, there is the Nezhdaninskoye deposit, one of the largest ore deposits in Russia, with reserves of more than 600 tons of gold. Polymetal is currently preparing to start developing Nezhdaninskoye in 2022 (Polymetal International PLC, 2020).

The Arctic Zone stands out with reserves of gold ore and alluvial gold that are concentrated in the Kyuchus deposit with about 200 tons of gold in the unallocated subsoil fund. In addition to gold, the Arctic has promising diamonds placers (Grigoryeva, 2019) and rare-earth elements reserves of the Tomtor deposit (Tolstov et al,. 2017). The main challenge of the development of Arctic resources is power supply. To solve this problem, the following projects were proposed (Melnikov et al., 2012; Davaakhuu et al., 2019):

- phased development of the Zyryansky open pit with annual production volumes of up to 2.0 million tons;

- briquetting of brown coal and (or) peat at the peat deposits in the Verkhoyansky District (2.9 million tons) to be used as household fuel;

- creation of the Taimylyr fuel and energy complex on the basis of the same-name coal mine.

It is also planned to establish new industrial facilities to extract silver and tin as part of the NorthYakutia Support Zone (Kondratyeva, 2017).

At the same time, it must be noted that in the North mining operations pose a threat to local communities that depend on reindeer breeding and hunting. In territories where extraction of minerals is a new industry, such business activity is regarded as opposed to the local small-scale economy. L. Suopajärvi et al. (2017) outlined the impact frame that centers on experiences and concerns about the dependency of a community on a single industry. When the fortunes of local communities are dependent on international business and the fluctuations of global markets, the residents feel that they have no power to influence the developments and can thus only adapt.

\section{CONCLUSIONS}

The spatial formation and development of the regional extractive economy in the $\mathrm{RS}(\mathrm{Ya})$ is based on the cluster organization of subsoil use, which is a new form of production relations between the economic structures, consisting of the large companies and the transport and power supply infrastructure.

The methodology for studying the structuring and effective organization of the economic space in general builds upon the functional properties of the spatial organization of production and the placement of industrial and transport hubs, agglomerations, territorial production complexes and various settlements.

The growth point of the territorial-industrial cluster, and subsequently the entire region, can be any network of subsoil users that is born by intra-regional, inter-regional, national, and international demand transmitted through market relations between companies, zones and regions; 
The subsoil use in the North is marked by the focal development of highly liquid and easily accessible mineral deposits with favorable mining, geological and technological conditions, justifying costly transportation and infrastructure. It is the main factor affecting the asymmetric development of regions.

Zoning based on the cluster organization of subsoil use industries can increase the investment attractiveness and competitiveness of raw materials deposits in remote northern regions, which will play an important role in eliminating the imbalance in their economic and social development.

The creation of clusters should be a priority in the economic policy aimed at increasing the competitiveness of regions that provides a synergy effect.

The assessment of cluster territories and actions taken by local governments makes it possible to identify the existing trends, the threats and the growth points. It is a means of generalizing the information that is required to establish an effective socio-economic policy in the system of state and municipal government.

The results of the study can be used in regional economy management and as educational aids for undergraduate and postgraduate students who major in Regional Economics. The proposed comprehensive assessment method can be applied in strategic planning at the regional and subregional levels.

\section{REFERENCES}

Antonov, I.Y., Argunov, V.G., Aprosimova, Y.P., Barakhova, V.V., Barashkova, A.S., Bashkirov, M.B., Baisheva, S.M. (2019). Productive forces of Western Yakutia: Results of comprehensive scientific research in 2017. Barnaul: IP Kolmogorov.

Bereznev, S.V., Kulpina, E.E. (2018). Theories of economic growth and development: foreign experience and domestic practice. Economics and Innovation management, 2, 4-11.

Davaakhuu, N., Potravny, I.M., Miloslavsky, V.G., and Utkin, I.I. (2019). Rationale and mechanism for implementing the coal gasification project in the Russian Arctic. Coal, 9, 1122.

De Sa, P. (2019). Mining and sustainable development: territorializing the mining industry. Miner Econ, 32, $131-143$.

Efremov, E.I., Kovrov, G.S., Nikiforova, V.V., Egorov, N.Y., and Konstantinov, N.N. (2016a). Modern problems of spatial organization of regional subsoil use economy of the Republic of Sakha (Yakutia). In: Republican Scientific-Practical Conference Second Yakut Integrated Expedition: Beginning of the Way, 27 December 2016, Yakutsk, Russia.

Efremov, E.I., Kovrov, G.S., Nikiforova, V.V., and Konstantinov, N.N. (2017). Cluster Approach to Development of Main Subsoil Use Industries in Yakutia. Yakutsk: North Eastern Federal University.

Efremov, E.I., Kovrov, G.S., Nikiforova, V.V., Konstantinov, N.N., and Kurneva, M.V. (2016b). Assessment of the potential of clusterization of fuel and energy complex of the Sakha republic (Yakutia). Indian Journal of Science and Technology, 9 (22), 1-12.

Egorov, N.Y., Babkin, A.V., and Kovrov, G.S. (2015). A methodological approach to assessing the potential of regional industrial clusters based on the triple helix model. In: Scientific and Practical Conference 'Restructuring of the Economy of Russia and Industrial Policy (INDUSTRY-2015), 23-24 March 2015, Saint Petersburg, Russia.

Enright, M.G. (1993). Regional Clusters and Economic Development: A Research Agenda. Harvard Business School, Boston.

Federal State Statistic Service for the Republic of Sakha (Yakutia) (2019). Basic socio-economic indicators of the municipalities of the Republic of Sakha (Yakutia) in January-December 2018. Statistical bulletin. Yakutsk. 
Federal State Statistic Service for the Republic of Sakha (Yakutia) (2020). Official statistics for the Republic of Sakha (Yakutia). https://sakha.gks.ru/folder/32356

Foray, D., David, P., and Hall, B. (2009). Smart specialization - The concept. Knowledge Economists Policy Brief, 9. https://ec.europa.eu/invest-in-research/pdf/download_en/kfg_policy_brief_no9.pdf

Fujita, M., and Krugman, P. (1995). When is the economy monocentric: von Thunen and Chambertin unified. Regional Science and Urban Economics, 25 (4), 505-528.

Gourley, A.C. (2019). Key elements of a model mining code: a Middle East case study. Miner Econ, 32, 187-204.

Grigoryeva, E.E. (2019). Diamond mining in the Arctic: Influence of industrial potential on social and economic systems. IOP Conference Series: Earth and Environmental Science, 302 (1), 012138.

Gulyaev, P.V., Barashkova, A.S., Batugina, N.S., Vasilyeva, F.D., Gavrilov, V.L., Grigoryev, V.P., Grigoryeva, E.E. (2019). Southern Yakutia: Resource potential of socio-economic complexes. Ufa: Aeterna.

Isard, W. (1960). Methods of Regional Analysis. MIT Press, Cambridge.

Kolchinskaya, Y.E., Limonov, L.E., and Stepanova, Y.S. (2019). Are clusters instrumental for the development of industrial enterprises in former planned economies? Spatial Economics, 15 (4), 126-148.

Kolmar Coal Mining Company (2020). Strategy. http://www.kolmar.ru/company/strategy/

Kolomak, Y.A., Kryukov, V.A., Melnikova, L.V., Seliverstov, V.Y., Suslov, V.I., and Suslov, N.I. (2018). Spatial development strategy of Russia: Expectations and realities. Region: Economics and Sociology, 2 (98), 264-287.

Kondratyeva, V.I. (2017). North Yakutian basic area of the Arctic zone of Russia in the strategy of spatial development of the Russian Federation. Arctic XXI century. Humanities, 1 (11), 4-12.

Krugman, P. (1995). Development, Geography and Economic Theory. MIT Press, Cambridge.

Lösch, A. (2007). Die raumliche Ordnung der Wirtschaft. (V.N. Streletsky, trans.). Moscow: Nauka.

Melnikov, A.Y., Kolodeznikov, I.I., Pavlov, S.S., and Protopopov, A.V. (2012). Features of Tabalakh group peat deposits and assessment of the possibility of its use as boiler fuel for the needs of the Verkhoyansky district of the Republic of Sakha (Yakutia). Science and Education 4, 24-28.

Minakir, P.A., and Prokapalo, O.M. (2018). Far East priority: Combinations of investment and institutes. Journal of The New Economic Association, 2 (38), 146-155.

Murdal, G. (1957). Economic Theory and Underdeveloped Regions. London: Duckworth.

Naumov, I.V., Sedelnikov, V.M., and Averina, L.M. (2020). Evolution of the spatial development theories: Principal features and modern objectives of research. Journal of Economic Theory, 17 (2), 383-398.

Nikiforova, V.V. (2020). Methodological approaches to the assessment of spatial differentiation of the basic sectors of subsoil use of the Republic of Sakha (Yakutia). IOP Conf Ser Mater Sci Eng, 753, 072008.

Okun, A.M. (1975). Equality and efficiency: The big tradeoff. Brookings Institution, Washington, D.C.

Palander, T. (1935). Beitrage zur Standortstheorie. Almqvist and Wiksell, Uppsala.

Polymetal International PLC (2020). Key Facts. https://www.polymetalinternational.com/ru/assets/growthprojects/nezhda/

Porter, M. (1993). The Competitive Advantage of Nations (I.V. Kvasyuk, trans.). Moscow: Mezhdunarodnye Otnosheniya. 
Rosenfeld, S.A. (1997). Bringing Business Clusters into the Mainstream of Economic Development. Eur Plan Stud, 5, 3-23.

Shagiyeva, I.T. (2013). Russian and foreign experience in managing the development of regions in the period of economic modernization. Young Scientist, 3 (50), 302-304. https://moluch.ru/archive/50/6288/

Shutilov, F.V. (2013). Methods of assessment of efficiency and synergetic effect of clusters. Scientific bulletin of the Southern Institute of Management, 2, 81-85.

Suopajärvi, L., Ejdemo, T., Klyuchnikova, E., Korchak, E., Nygaard, V., and Poelzer, G.A. (2017). Social impacts of the 'glocal' mining business: case studies from Northern Europe. Miner Econ, 30, 31-39.

Tolstov, A.V., Pokhilenko, N.P., and Samsonov, N.Y. (2017). New opportunities for producing rare earth elements one of the Arctic raw material source. Journal of Siberian Federal University. Chemistry, 10 (1), 125138.

Treyvish, A.I. (2019). Uneven and structurally diverse spatial development of economy as a scientific problem and Russian reality. Spatial Economics, 15 (4), 13-35.

Weber, A. (1926). Über den Standort der Industrie (Russian edition, translated by Morozova N). MoscowLeningrad: Kniga. 